В. В. Тютюник, В. Д. Калугін, О. О. Писклакова

Національний університет цивільного захисту України, Харків, Україна

\title{
ОСНОВОПОЛОЖНІ ПРИНЦИПИ СТВОРЕННЯ У ЄДИНІЙ ДЕРЖАВНІЙ СИСТЕМІ ЦИВІЛЬНОГО ЗАХИСТУ ІНФОРМАЦЙНО-АНАЛІТИЧНОӤ ПІДСИСТЕМИ УПРАВЛІННЯ ПРОЦЕСАМИ ПОПЕРЕДЖЕННЯ Й ЛОКАЛІЗАЦІЇ НАСЛІДКІВ НАДЗВИЧАЙНИХ СИТУАЦІЙ
}

\begin{abstract}
Предметом вивчення в статті $є$ процеси: збору, обробки та аналізу інформації; моделювання розвитку обстановки на об'єкті управління та розвитку надзвичайної ситуації (НC) на території міста, регіону, держави; розробки та ухвалення управлінських рішень в умовах багатокритеріальності та невизначеності при попередженні та ліквідації НC, а також мінімізації їх наслідків для вирішення прикладних завдань Єдиної державної системи цивільного захисту (ЄДСЦЗ). Метою є розвиток науково-технічних основ створення інформаційно-аналітичної підсистеми управління процесами попередження й локалізації наслідків НС Єдиної державної системи цивільного захисту. Завдання: технічна реалізація у СДСЦЗ інформаційно-аналітичної підсистеми управління процесами попередження й локалізації наслідків НС шляхом комплексного включення в діючу ЄДСЦЗ по вертикалі від об'єктового до державного рівнів різних функціональних елементів територіальної системи моніторингу НС та складових системи ситуаційних центрів. Використовуваними методами є: методи системного, функціонального та випуклого аналізу; методи розробки автоматизованих систем; методи прийняття рішень в умовах багатокритеріальності та невизначеності. Отримані результати. Викладені основні принципи створення інформаційно-аналітичної підсистеми управління процесами попередження й локалізації наслідків НС у СДСЦЗ. Висновки. Наукова новизна отриманих результатів полягає в наступному: визначено, що однією з основних функцій системи ситуаційних центрів на всіх рівнях управління ЄДСЦЗ є розробка ефективних антикризових рішень, яка ускладнюється необхідністю урахування їх своєчасності, повноти й оптимальності. Для підвищення ефективності прийняття рішень обгрунтовано необхідність розробки формальних, нормативних методів і моделей комплексного рішення проблеми в умовах багатокритеріальності й невизначеності при управлінні процесами попередження й локалізації наслідків НС.
\end{abstract}

Ключ ов і слов а : надзвичайна ситуація, Єдина державна система цивільного захисту, інформаційно-аналітична система управління процесами попередження й локалізації наслідків надзвичайних ситуацій, система моніторингу надзвичайних ситуацій, система ситуаційних центрів, прийняття рішень в умовах багатокритеріальності й невизначеності.

\section{Вступ}

Постановка проблеми. Територія України, як система 3 територіально-часовим розподілом параметрів життєдіяльності - рис. 1, у процесі свого функціонування та розвитку створює передумови для виникнення небезпек, які негативно впливають на стан природно-екологічного, економіко-технічного та соціально-політичного балансу на її території.

У відповідності до рис. 1, джерело інтегральної небезпеки в точці $A(x, y, z)$ території нелінійно об'єднує джерела природної небезпеки [1-6]: 1'процеси у атмосфері; 2' - процеси у біосфері; 3' процеси у літосфері; 4' - процеси у гідросфері; джерела техногенної небезпеки [4]: 1" - аварії на промислових об'єктах і транспорті; 2" - вибухи; 3" - пожежі; 4" - вивільнення інших видів енергії; джерела соціальної небезпеки [7]: $1^{\prime \prime \prime}$ - психологічні особливості особи й особливості виховання; $2^{\prime \prime \prime}$ несприятливе положення особи; $3^{\prime \prime \prime}$ - соціальна несправедливість; 4"' - напруженість у міжгрупових, міжконфесійних і міжнаціональних стосунках; $5^{\prime \prime \prime}$ негативні соціальні процеси, що призводять до руйнування етичних засад, соціальної стійкості особи та законослухняності; джерела воєнної небезпеки [7]: $1^{\prime \prime \prime \prime}$ - наявність гострих суперечностей, розв'язання яких $\epsilon$ можливим лише із застосуванням воєнної сили; 2"'" - наявність у однієї із сторін достатньої кількості військових сил і засобів для розв'язання су-

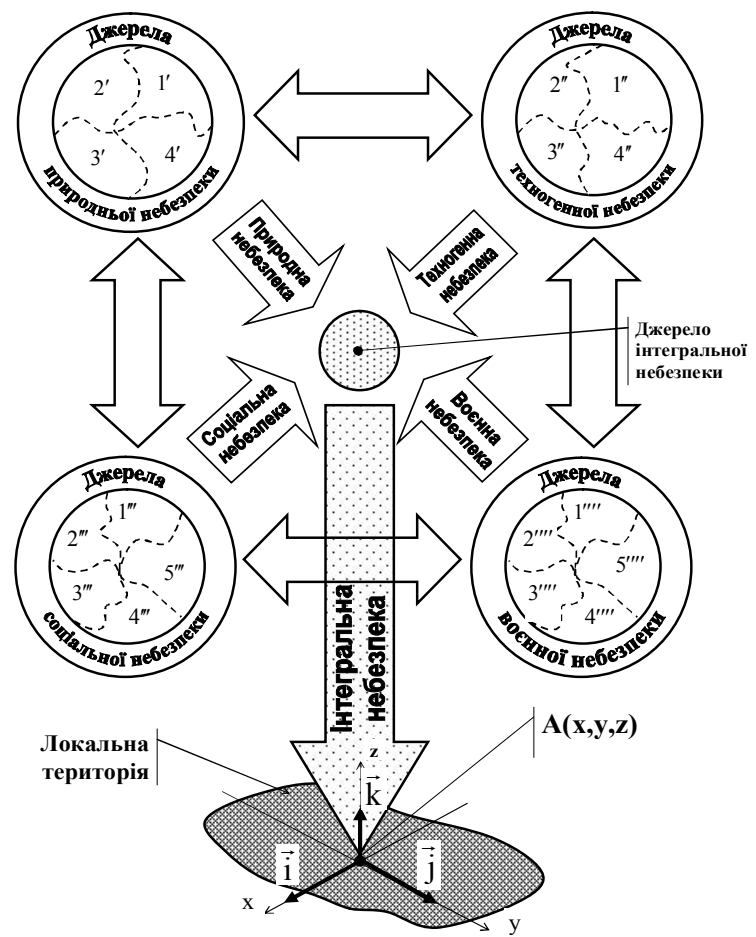

Рис. 1. Модельне представлення процесів зародження на локальній території джерел надзвичайних ситуацій різного походження та результат апроксимації територіï НC

перечності на свою користь або здатність держави створити такі сили в перспективі; $3^{\prime \prime \prime \prime}$ - наявність у 
лідерів або урядів політичної волі та рішучості піти на застосування сили, здатності використовувати збройні сили для вирішення можливого конфлікту; $4^{\prime \prime \prime \prime}$ - наявність надійних союзників серед держав, їх коаліцій або інших суб'єктів військово-політичних відносин; 5"'" - сприятливі геополітичні умови та реальна (або прогнозована) військово-політична обстановка для здійснення військових акцій.

В Україні для забезпечення реалізації державної політики у сфері цивільного захисту функціонує ЄДСЦЗ, функціональну схему якої приведено на рис. 2. Система складається 3 функціональних і територіальних підсистем та спрямована на розв'язання питань забезпечення необхідного рівня безпеки життєдіяльності території держави лише в умовах, коли виникла НС. При цьому, цілковито відкритими для держави залишаються проблемні питання реалізації в системі СДСЦЗ функції моніторингу та розробки ефективних управлінських рішень, спрямованих на попередження та локалізацію $\mathrm{HC}$, в умовах зародження джерел небезпек різної природи.

Це вказує на необхідність термінового розв'язання питань включення до складу СДСЦЗ інформаційно-аналітичної підсистеми управління процесами попередження й локалізації наслідків НС.

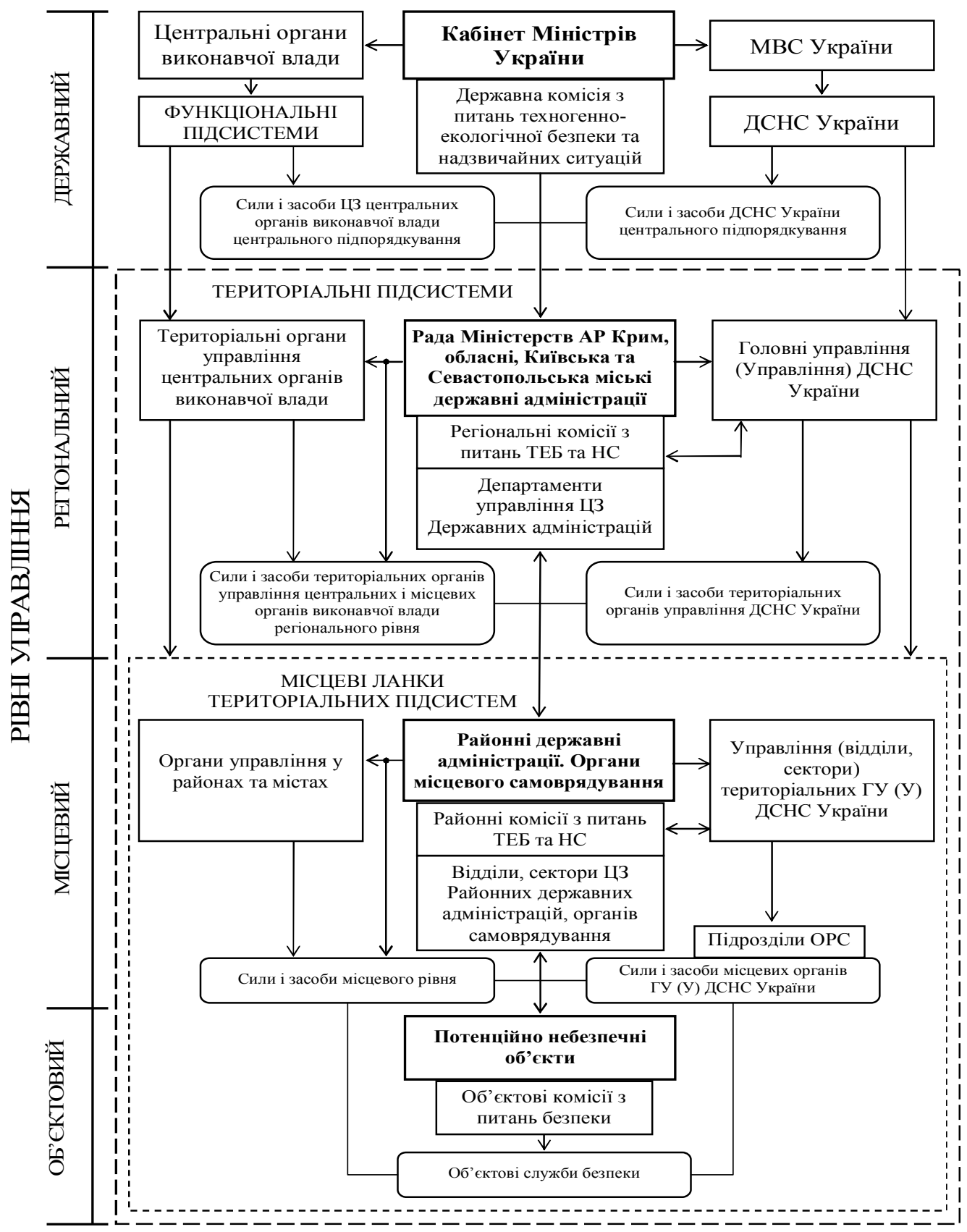

Рис. 2. Функціональна схема діючої в Україні Єдиної державної системи цивільного захисту

Аналіз останніх досліджень і публікацій. Згідно стратегії реформування Державної служби України з надзвичайних ситуацій (ДСНС України)
[8], серед актуальних напрямків удосконалення функціонування ЄДСЦЗ необхідно визначити низку проблемних питань науково-інформаційно- 
технологічного характеру, які стосуються оптимального управління процесами попередження, локалізації та ліквідації наслідків надзвичайних ситуацій, а саме:

1. Удосконалення механізму взаємодії ДСНС України з іншими структурами усіх рівнів забезпечення національної безпеки шляхом подальшого розвитку державного центру управління в надзвичайних ситуаціях ДСНС України, утворення відповідних регіональних центрів та налагодження їх взаємодії з Головним ситуаційним центром та іншими ситуаційними центрами складових сектору безпеки і оборони.

2. Запровадження системи управління усіма видами техногенної безпеки (з вивільненням різних видів енергії) на основі ризико-орієнтованого підходу і європейських стандартів щодо оцінювання i аналізу ризиків цих видів техногенної безпеки суб'єктів господарювання.

3. Створення та забезпечення функціонування автоматизованої системи управління телекомунікаційними мережами, центру обробки даних, комплексної підсистеми інформаційної підтримки прийнят- тя рішень та їх виконання з питань НС, у тому числі комплексної системи захисту інформації.

\section{Постановка задачі та їі розв'язання}

Метою цієї роботи є розвиток науковотехнічних основ створення інформаційно-аналітичної підсистеми управління процесами попередження й локалізації наслідків НС Єдиної державної системи цивільного захисту шляхом технічної реалізації, згідно стратегії реформування ДСНС України, системи ситуаційних центрів.

Основу цивільного захисту держави повинен становити класичний контур управління (рис. 3), який забезпечить:

1) збір, обробку та аналіз інформації;

2) моделювання розвитку обстановки на об'єкті управління та розвитку НС на території міста, регіону, держави;

3) розробку та ухвалення управлінських рішень щодо попередження та ліквідації $\mathrm{HC}$, а також мінімізації їх наслідків;

4) виконання рішень щодо попередження та ліквідації НС, а також мінімізації їх наслідків [4].

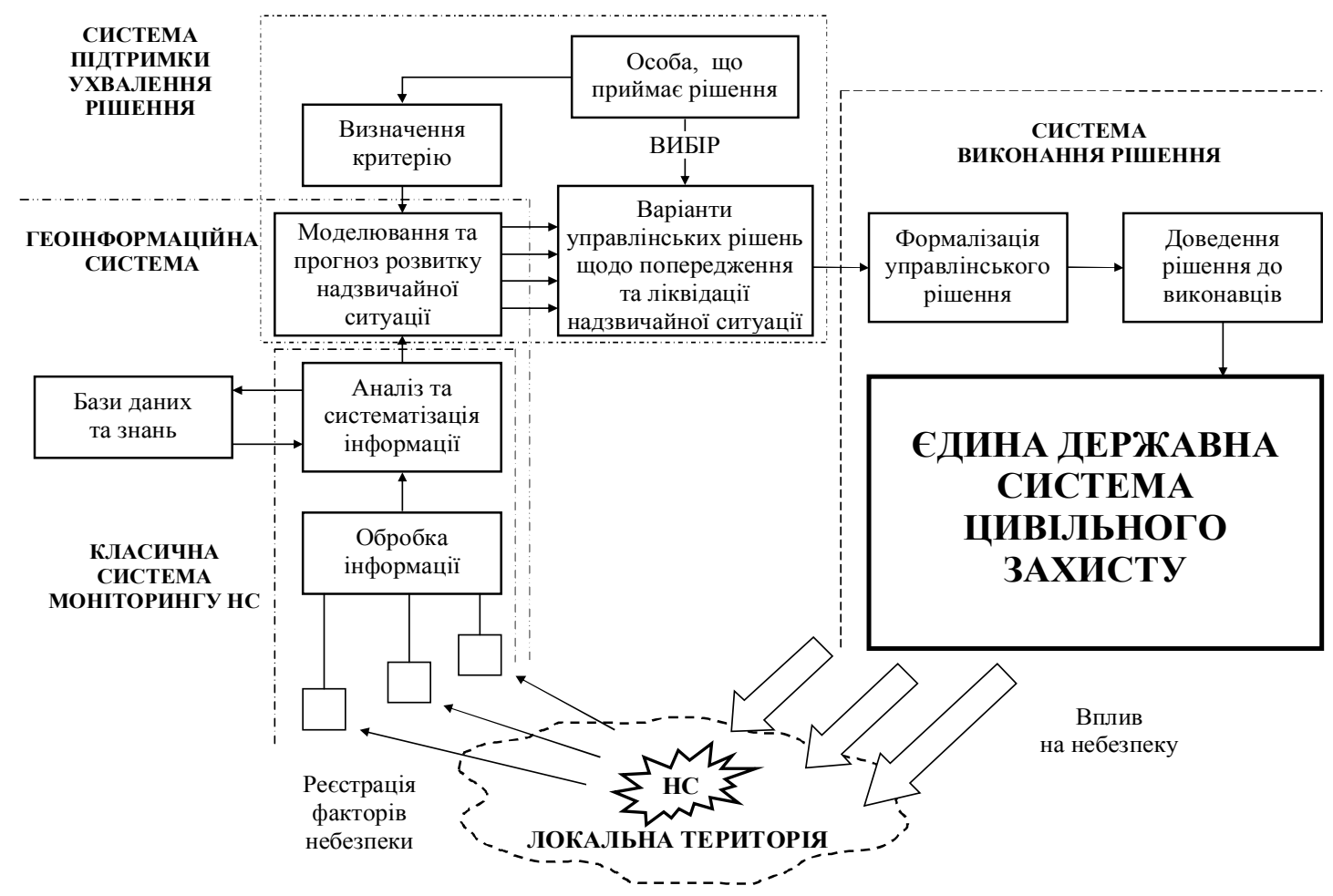

Рис. 3. Схема класичного контуру управління, щодо реалізації функцій моніторингу, попередження та ліквідації НС, а також місце існуючої ЄДСЦЗ в цьому контурі

Отримана засобами контролю первинна інформація про фактори небезпеки на локальній території (місто, регіон, держава) або потенційно небезпечному об'єкті по кабелях або радіоканалу транслюється до пристроїв другого рівня, які призначені виконувати обробку отриманої інформації та представляти iii у вигляді, необхідному для третього рівня.

Обробка отриманої інформації може виконуватися як в одному місці, так і на декількох, залежно від конкретної системи моніторингу та розмірів ко- нтрольованої нею локальної території. Оброблена інформація у відповідному вигляді надходить на третій рівень, де виконується іiї аналіз та систематизація даних, на основі чого робиться висновок про стан небезпеки локальної території. Особливо важливо для забезпечення швидкодії системи використання автоматизованих засобів обробки інформації, яке значно прискорить процеси на другому та третьому рівнях системи моніторингу, дозволить створити електронні, доступні в реальному масштабі 
часу, бази даних та знань. Використання відповідних математичних методів дозволить на основі отриманої інформації у відносно нетривалі терміни часу виконати моделювання небезпечної ситуації, прогнозування iї розвитку та рівня, відображати прогнозовану динаміку катастрофічних подій графічно (у тому числі з використанням мап).

Друга інформаційна система $є$ системою підтримки ухвалення рішення. Особа, що приймає рішення (ОПР), визначає один або декілька критеріїв, відповідно до яких здійснюється прогностичне моделювання розвитку НС та виробляються варіанти управлінських рішень, які обгрунтовані відповідними розрахунками. 3 набору варіантів управлінських рішень ОПР обирає один, або задає ще додаткові критерії, відповідно до яких виконується моделювання та розробка управлінських рішень, направлених на недопущення розвитку небезпеки до рівня катастрофи. Якщо ж катастрофи вже не уникнути, то розробка управлінських рішень направлена на мінімізацію наслідків від неї. Затверджене ОПР рішення надходить до третьої системи - системи виконання рішення, де виконується його формалізація та доведення до виконавців - функціонуючої в Україні ЄДСЦЗ. Зміни стану локальної території та зміни стану небезпеки на ній викликатимуть зміни у величинах вимірюваних параметрів, що фіксуються пристроями контролю.

Подальше моделювання покаже ефективність виконання управлінського рішення - контур управління замкнувся.

3 метою створення інформаційно-аналітичної підсистеми управління процесами попередження й локалізації наслідків НС в роботі пропонується в діючу систему ЄДСЦЗ, функціональну схему якої представлено на рис. 2, по вертикалі від об'єктового до державного рівнів (базуючись на уявленнях, що основу ЄДСЦЗ у відповідності до рис. 3 повинен становити класичний контур управління) комплексно включити різні функціональні елементи системи моніторингу НС на території держави [1 -7, 9] та складові системи ситуаційних центрів, які жорстко пов'язані між собою на інформаційному та виконавчому рівнях для прийняття ефективних антикризових рішень при розв'язанні різних функціональних задач моніторингу, попередження та ліквідації НС природного, техногенного, соціального та воєнного характеру (модельне представлення процесів зародження на локальній території джерел НС різного походження представлено на рис. 1).

На базі вищевикладеного, комплексну функціональну схему інформаційно-аналітичної підсистеми управління процесами попередження й локалізації наслідків НС ЄДСЦЗ, що об'єднала систему моніторингу НС та систему ситуаційних центрів представлено на рис. 4.

Згідно існуючої законодавчої бази України [10, 11], основними завданнями діючої в державі ЄДСЦЗ $\epsilon$ такі:

1) забезпечення готовності міністерств та інших центральних та місцевих органів виконавчої влади, органів місцевого самоврядування, підпоряд- кованих їм сил і засобів до дій, спрямованих на запобігання і реагування на $\mathrm{HC}$;

2) забезпечення реалізації заходів щодо запобігання виникненню НС;

3) навчання населення щодо поведінки та дій у разі виникнення $\mathrm{HC}$;

4) виконання державних цільових програм, спрямованих на запобігання НC, забезпечення сталого функціонування підприємств, установ та організацій, зменшення можливих матеріальних втрат;

5) опрацювання інформації про НС, видання інформаційних матеріалів з питань захисту населення і територій від наслідків НС;

6) прогнозування i оцінка соціально-економічних наслідків НС, визначення на основі прогнозу потреби в силах, засобах, матеріальних та фінансових ресурсах;

7) створення, раціональне збереження і використання резерву матеріальних та фінансових ресурсів, необхідних для запобігання і реагування на $\mathrm{HC}$;

8) оповіщення населення про загрозу та виникнення НС, своєчасне та достовірне інформування про фактичну обстановку і вжиті заходи; захист населення у разі виникнення $\mathrm{HC}$;

9) проведення рятувальних та інших невідкладних робіт щодо ліквідації наслідків НС, організація життєзабезпечення постраждалого населення; пом'якшення можливих наслідків НС у разі їх виникнення;

10) здійснення заходів щодо соціального захисту постраждалого населення;

11) реалізація визначених законом прав у сфері захисту населення від наслідків НС, в тому числі осіб (чи їх сімей), що брали безпосередню участь у ліквідації цих ситуацій.

Діюча в України система СДСЦЗ включає наступні елементи: суб'єкт управління (підсистеми) органи державної влади, що здійснюють розробку та реалізацію державної політики у сфері цивільного захисту; об'єкт управління (підсистеми) - сфера цивільного захисту як система забезпечення безпеки життєдіяльності населення держави; управлінська діяльність (процеси) - організація суспільних відносин, що забезпечує прямі та зворотні зв'язки між суб'єктом та об'єктом управління. ЄДСЦЗ складається 3 постійно діючих функціональних і територіальних підсистем та їх ланок.

Функціональні підсистеми ЄДСЦЗ створюються у відповідних сферах суспільного життя центральними органами виконавчої влади з метою:

а) захисту населення і територій від НС у мирний час та в особливий період;

б) забезпечення готовності підпорядкованих їм сил і засобів до дій, спрямованих на запобігання i реагування на НC.

Безпосереднє керівництво діяльністю функціональної підсистеми здійснюється керівником органу чи суб'єкта господарювання, що створив таку підсистему.

Територіальні підсистеми СДСЦЗ створюються місцевими органами виконавчої влади в межах відповідних територій і складаються 3 ланок адмініст- 
ративно-територіального розподілу цих територій. Метою створення територіальних підсистем є здійснення заходів щодо захисту населення і територій від НС у мирний час та в особливий період у відпо- відному регіоні. Безпосереднє керівництво діяльністю територіальної підсистеми, іiі ланок здійснюється посадовою особою, яка очолює орган, що створив таку підсистему, ланку.

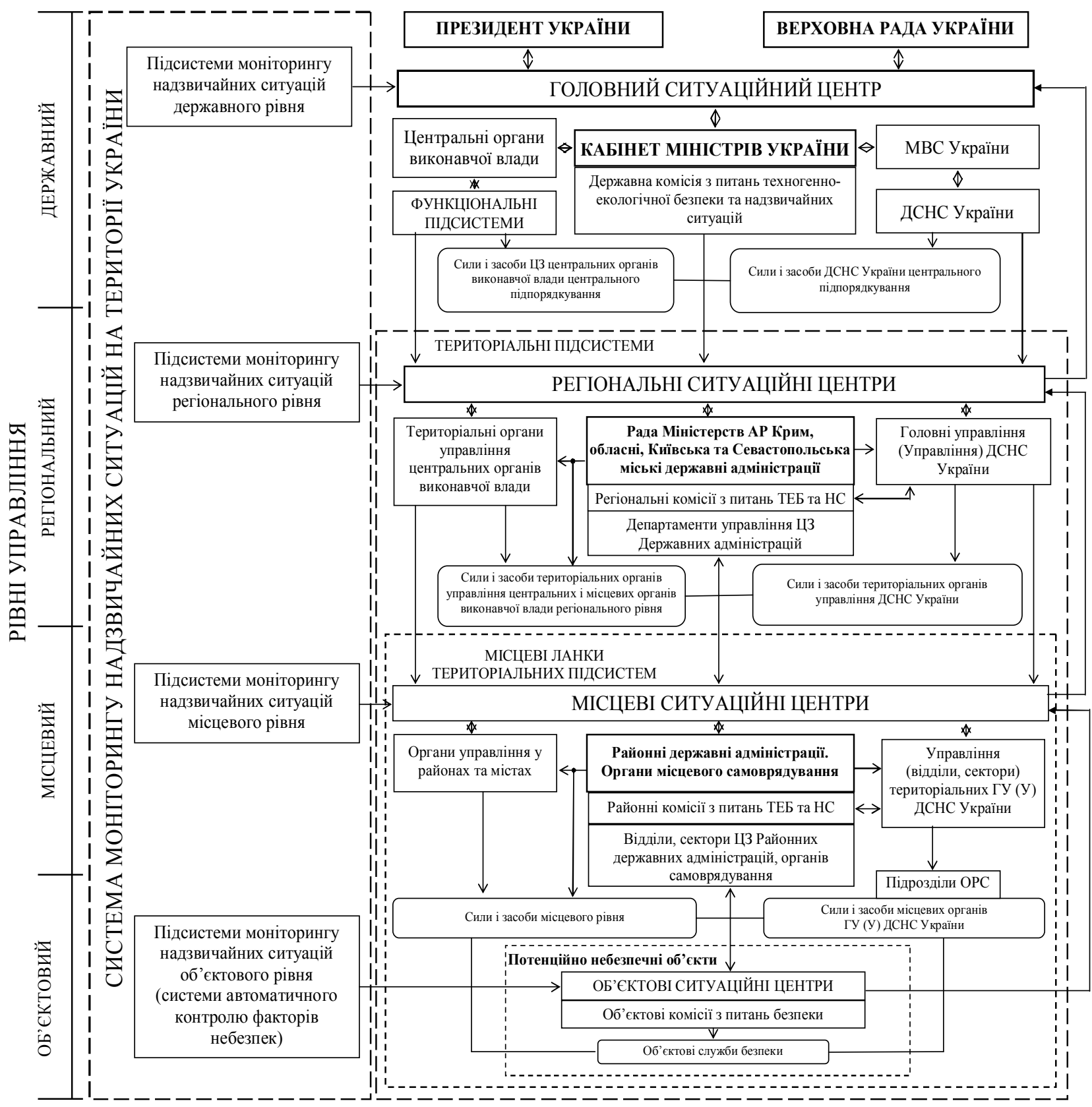

Рис. 4. Комплексна функціональна схема інформаційно-аналітичної підсистеми управління процесами попередження й локалізації наслідків НС Єдиної державної системи цивільного захисту

Підключення до ЄДСЦЗ системи моніторингу НС на території України [1 - 7, 9], як інструменту непереривного отримання у реальному масштабі часу інформації про територіально-часовий розподіл по території держави джерел різного роду небезпек, повинно бути реалізовано, у відповідності за даними рис. 4, на усіх чотирьох рівнях управління від об'єктового до державного.

Так, на об'єктовому рівні система моніторингу НС складається, у відповідності за даними рис. 5, 3 мобільних (пересувних) та стаціонарних засобів контролю факторів небезпек.
Мобільні (пересувні) та стаціонарні засоби моніторингу НС об'єктового рівня об'єднують такі засоби:

контролю доступу та периметру; контролю пожежної небезпеки; контролю радіаційної небезпеки; контролю хімічної небезпеки; контролю біологічної небезпеки; контролю вибухової небезпеки; контролю інформаційної небезпеки;

контролю стану безпеки персоналу та відвідувачів (засоби відеоспостереження); 


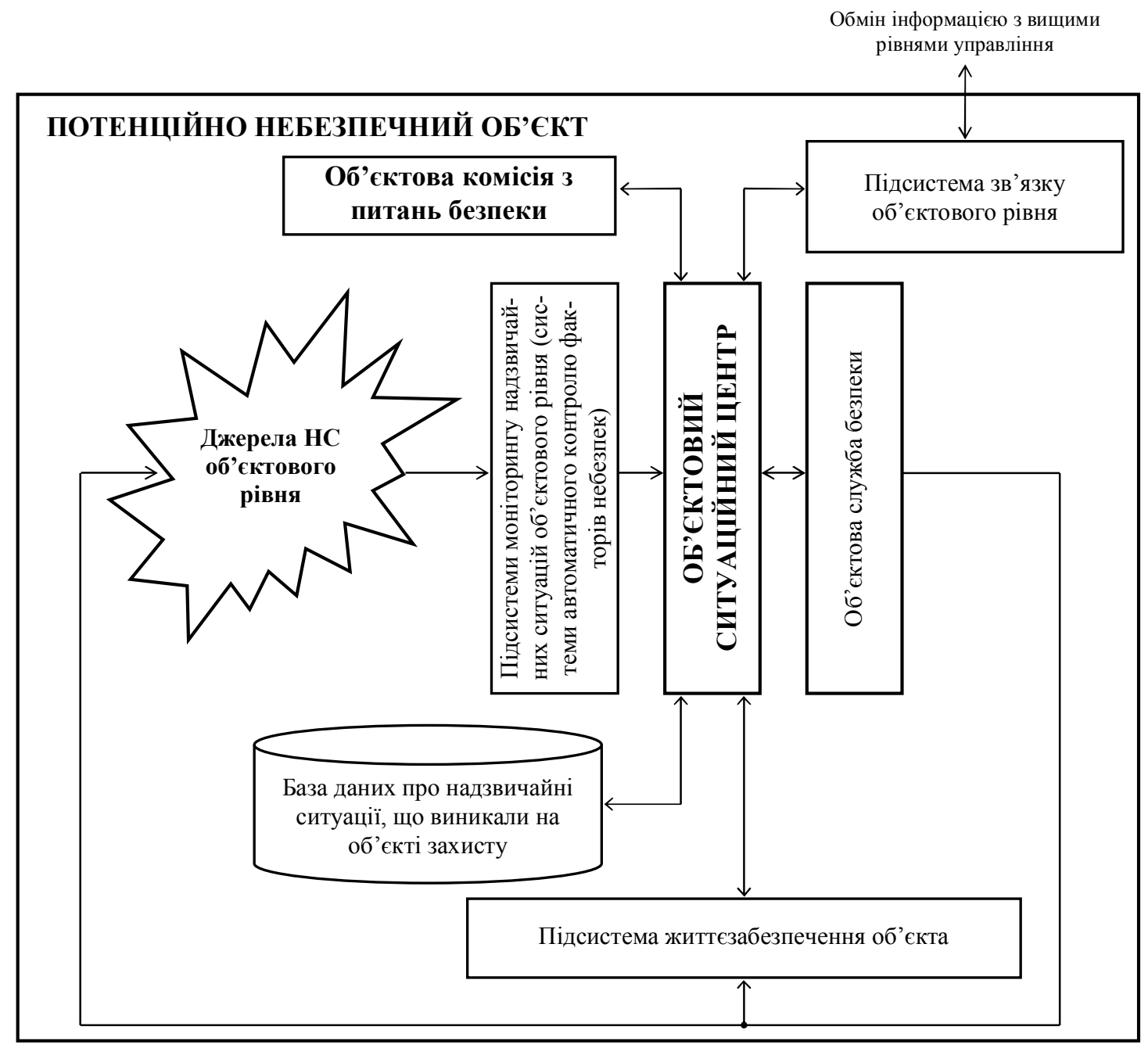

Рис. 5. Функціональна схема інформаційно-аналітичної підсистеми управління процесами попередження й локалізації наслідків НС об' єктового рівня

контролю інших небезпек, що пов'язані із специфікою об'єкта захисту.

Підсистема зв'язку об'єктового рівня включає засоби: Інтернет та Інтранет; структурованої кабельної системи; АТС та мобільного зв'язку; об'єктового серверу (віщання, трансляція тощо).

Об'єктова служба безпеки об'єднує сили і засоби $з$ попередження та ліквідації: проникнення та нападу на об'єкт; пожежної небезпеки; радіаційної, хімічної та біологічної небезпеки; вибухової небезпеки; інформаційної небезпеки; інших небезпек, що пов'язані із специфікою об'єкта захисту. Підсистема життєзабезпечення об'єкта включає засоби: тепло-, водопо-, енерго- та газопостачання; постачання холоду; забезпечення мікроклімату.

На рис. 6 представлена функціональна схема інформаційно-аналітичної підсистеми управління процесами попередження й локалізації наслідків НС місцевого рівня, які включають небезпеки, що виникли у районах міста.

На рис. 7 представлена функціональна схема інформаційно-аналітичної підсистеми управління процесами попередження й локалізації наслідків НС регіонального рівня, які включають небезпеки, що виникли у районах регіону. На місцевому та регіо- нальному рівнях системи моніторингу НС складаються, у відповідності за даними рис. 6 і 7, 3 мобільних (пересувних) та стаціонарних засобів контролю факторів небезпек наземного, повітряного та водного базування, а також поділяються на підсистеми моніторингу НС природного, техногенного та воєнного характеру.

Так, на державному рівні управління аналізу та протидії підлягають НС, які виникають в одному або декількох регіонах держави, у разі, коли територіальні підсистеми ЄДСЦЗ окремих регіонів не можуть впоратись 3 небезпекою відповідного рівня, а також НС, які виникають із зовні держави.

Надзвичайні ситуацій, які виникають із зовні держави, складаються 3 небезпек, які виникають в: інших державах; навколоземному, ближньому та дальньому космосі - Космосфері [12]; в надрах Землі.

Мобільні (пересувні) та стаціонарні засоби моніторингу НС державного рівня об'єднують космічну систему дистанційного контролю території, а також наземні системи гідрометеорологічного прогнозу, системи сейсмічного, екологічного, радіаційного моніторингу та системи навігації та безпеки на авіаційному, залізничному, автомобільному та магістральному транспорті та інші. 


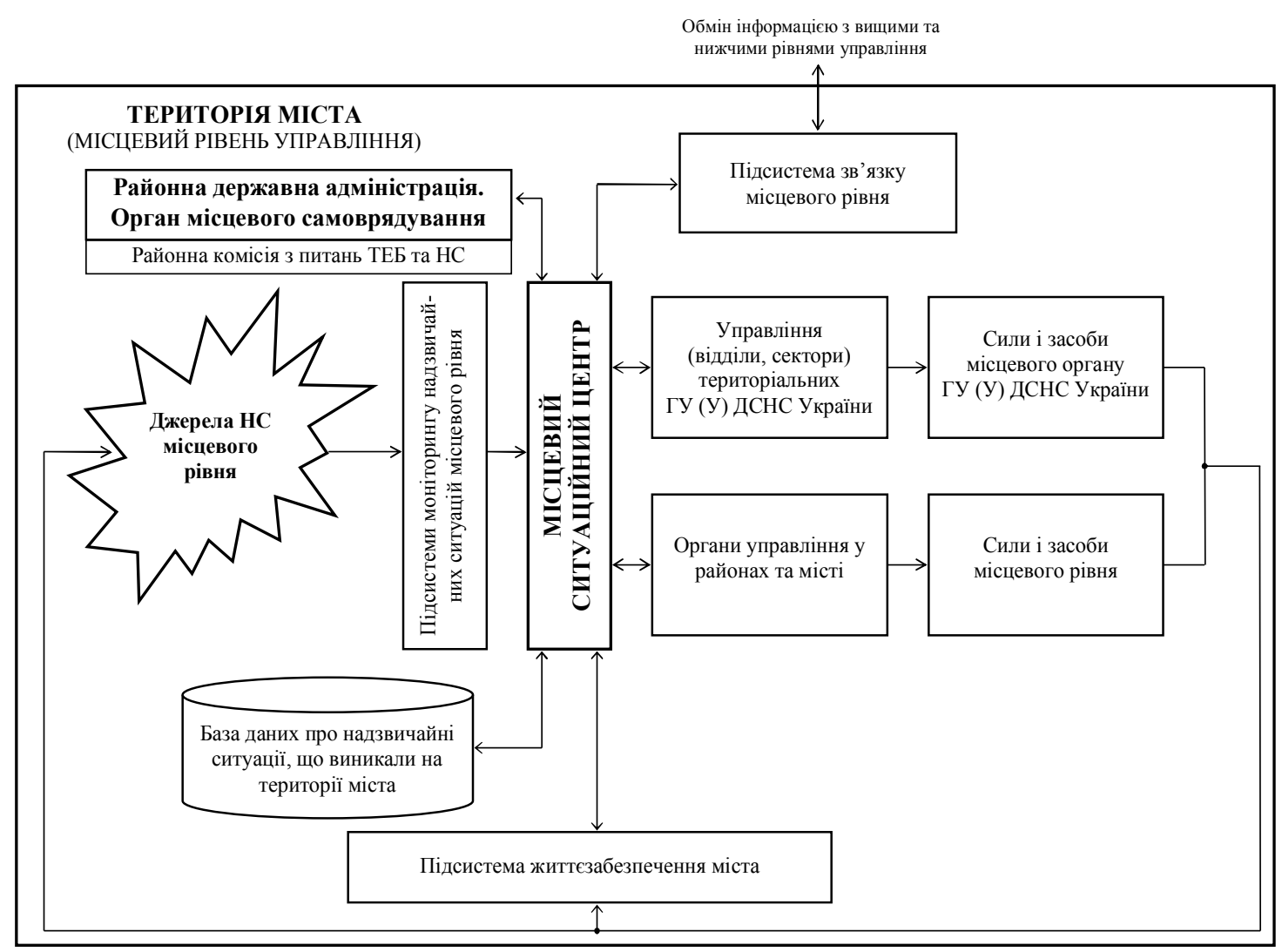

Рис. 6. Функціональна схема інформаційно-аналітичної підсистеми управління процесами попередження й локалізації наслідків НС місцевого рівня

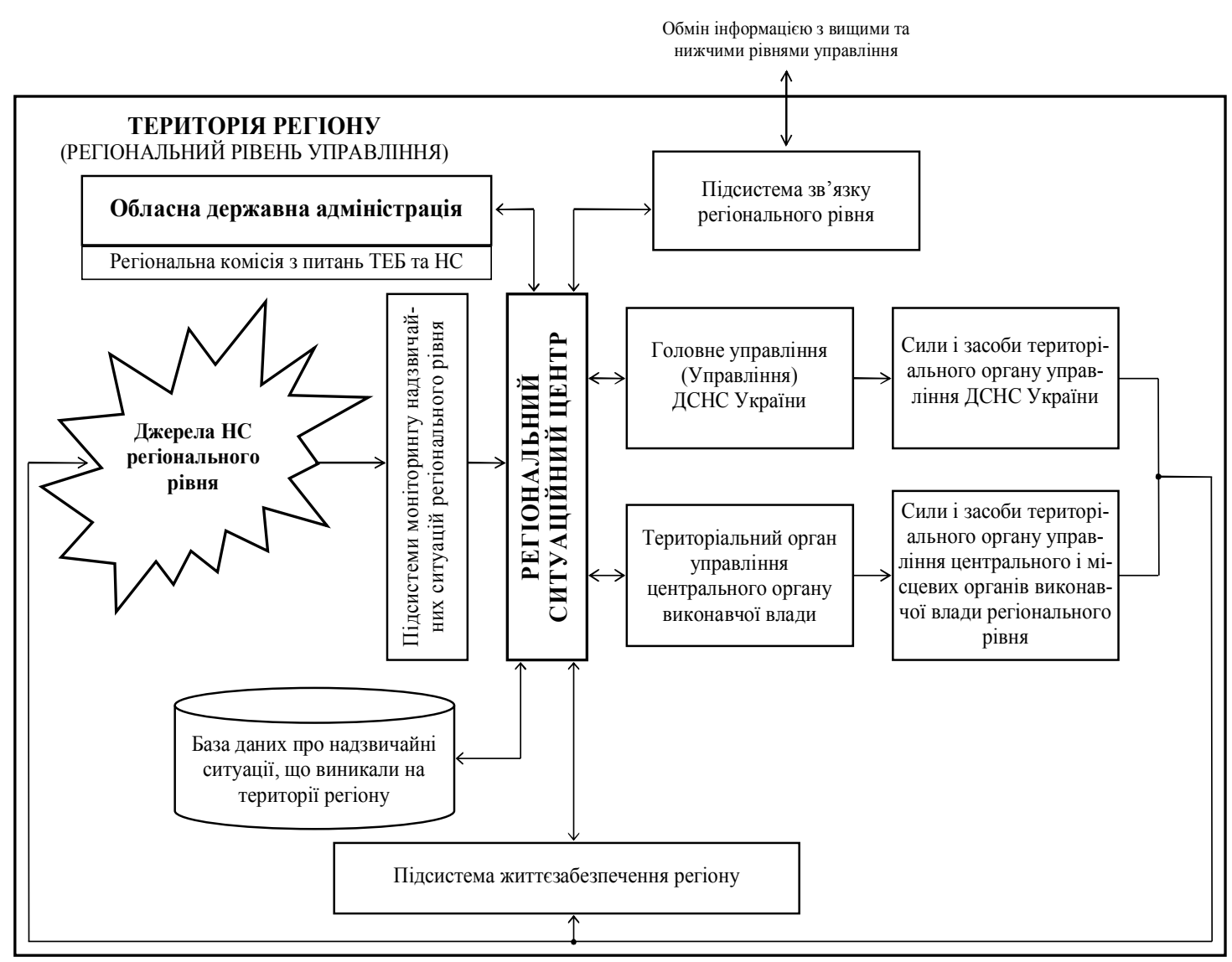

Рис. 7. Функціональна схема інформаційно-аналітичної підсистеми управління процесами попередження й локалізації наслідків НС регіонального рівня 
Основною функцією системи ситуаційних центрів на всіх рівнях управління ЄДСЦЗ є збір й обробка фактичної інформації, прогнозування ризику виникнення різного роду НС та розробка ефективних антикризових рішень. Процедура прийняття управлінських рішень щодо вирішення цих проблемних питань ускладнюється тим, що необхідними умовами ефективності рішень $\epsilon$ їх своєчасність, повнота й оптимальність [13]. Перераховані вимоги суперечливі і досягнення їх точності визначає актуальність проблеми прийняття ефективних рішень в галузі цивільного захисту.

Забезпечення повноти (комплексності) рішень вимагає як можна більш повного обліку внутрішніх і зовнішніх факторів, що впливають на ухвалення рішення, глибокого аналізу їх взаємозв'язків, що веде до росту розмірності задачі прийняття рішень, iї багатокритеріальності.

У свою чергу це приводить до росту невизначеності вихідних даних, що обумовлене неповнотою знань про взаємозв'язок факторів і, як наслідок, неточного іiі опису, неможливістю або неточністю виміру деяких факторів, випадкових зовнішніх і внутрішніх впливів тощо.

Додаткова складність полягає в тому, що невизначеності різнорідні й можуть бути представлені у вигляді випадкових або інтервальних величин та нечітких множин.

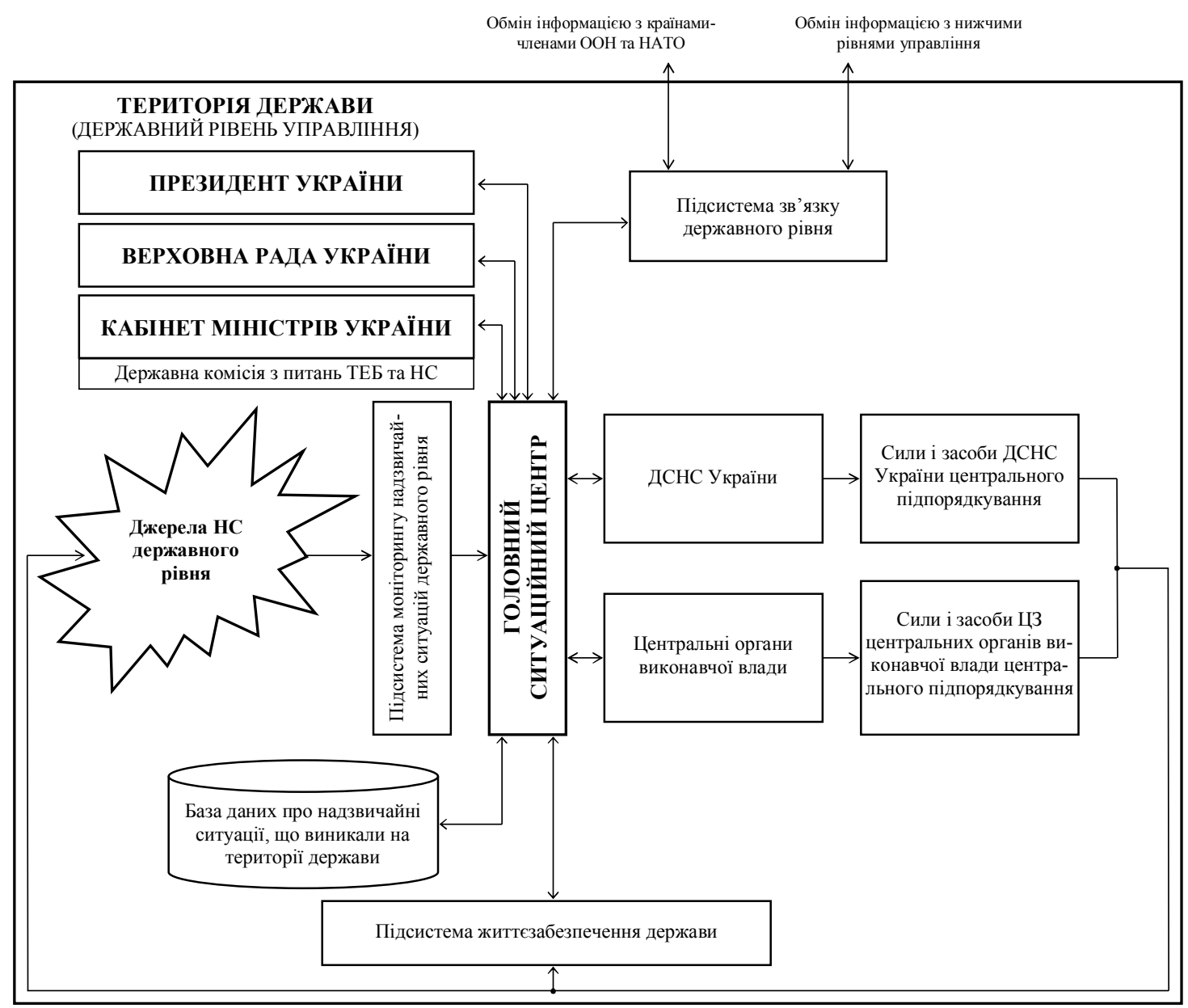

Рис. 8. Функціональна схема інформаційно-аналітичної підсистеми управління процесами попередження й локалізації наслідків НС державного рівня

Таким чином, підвищення ефективності прийнятих рішень пов'язане з необхідністю рішення задачі багатокритеріальної оптимізації в умовах невизначеності.

Традиційний, розповсюджений підхід до рішення таких задач, заснований на їх евристичному спрощенні та детермінізації як засобу зняття невизначеності, у міру ускладнення задач і підвищення значимості рішень стає усе менш ефективним [14-16].

У цих умовах виникає необхідність розробки формальних, нормативних методів і моделей комплексного рішення проблеми прийняття рішень в умовах багатокритеріальності й невизначеності при управлінні процесами попередження й локалізації наслідків НС для забезпечення ефективного функціонування ЄДСЦЗ.

\section{Висновки}

Викладені основні принципи створення інформаційно-аналітичної підсистеми управління процесами попередження й локалізації наслідків НС у єДСЦЗ:

1. Основу цивільного захисту держави становить класичний контур управління, який забезпечить: збір, обробку та аналіз інформації; моделю- 
вання розвитку обстановки на об'єкті управління та розвитку НС на території міста, регіону, держави; розробку та ухвалення управлінських рішень щодо попередження та ліквідації $\mathrm{HC}$, а також мінімізації їх наслідків; виконання рішень щодо попередження та ліквідації НС, а також мінімізації їх наслідків за умовах, що система виконання рішень реалізована функціонуючою в Україні СДСЦЗ.

2. Створити ефективну інформаційно-аналітичну систему управління процесами попередження й локалізації наслідків НС шляхом комплексного включення в діючу систему СДСЦЗ по вертикалі від об'єктового до державного рівнів різних функціональних елементів територіальної системи моніторингу НС та складових системи ситуаційних центрів, які жорстко пов'язані між собою на інформаційному та виконавчому рівнях для прийняття відповідних антикризових рішень для розв'язання різних функціональних задач моніторингу, попередження та ліквідації НС природного, техногенного, соціального та воєнного характеру.

3. Основною функцією системи ситуаційних центрів на всіх рівнях управління ЄДСЦЗ є збір й обробка фактичної інформації, прогнозування ризику виникнення різного роду НС та розробка ефективних антикризових рішень. Процедура прийняття управлінських рішень ускладнюється тим, що необхідними умовами ефективності рішень $€$ їх своєчасність, повнота й оптимальність. Тому, підвищення ефективності прийнятих рішень пов'язане з необхідністю рішення задачі багатокритеріальної оптимізації в умовах невизначеності, що потребує розробки формальних, нормативних методів і моделей комплексного рішення проблеми прийняття рішень в умовах багатокритеріальності й невизначеності при управлінні процесами попередження й локалізації наслідків НС для забезпечення ефективного функціонування СДСЦЗ.

\section{СПИСОК ЛІТЕРАТУРИ}

1. Черногор Л.Ф. Физика и экология катастроф / Л.Ф. Черногор - Харьков: Харьковский национальный университет имени В.Н. Каразина, 2012. - 556 с.

2. Тютюник В.В. Системний підхід до оцінки небезпеки життєдіяльності при територіально часовому розподілі енергії джерел надзвичайних ситуацій / В.В. Тютюник, Л.Ф. Чорногор, В.Д. Калугін // Проблеми надзвичайних ситуацій. Харків: Національний університет цивільного захисту України, 2011. - Вип. 14. - С. 171 - 194.

3. Калугін В.Д. Системний підхід до оцінки ризиків надзвичайних ситуацій в Україні / В.Д. Калугін, В.В. Тютюник, Л.Ф. Чорногор, Р.І. Шевченко // Восточно-Европейский журнал передовых технологий. - 2012. - 1/6 (55). - С. 59 70.

4. Андронов В.А. Науково-конструкторські основи створення комплексної системи моніторингу надзвичайних ситуацій в Україні: Монографія / В.А. Андронов, М.М. Дівізінюк, В.Д. Калугін, В.В. Тютюник. - Харків: Національний університет цивільного захисту України, 2016. - 319 с.

5. Тютюник В.В. Основи методології територіально-часового формування джерел надзвичайних ситуацій та екологічної небезпеки на локальній території / В.В. Тютюник, О.М. Соболь, В.Д. Калугін, Ю.В. Тютюник // Техногенноекологічна безпека та цивільний захист. - Київ: Інститут геохімії навколишнього середовища НАН України, 2015. Вип. 9. - С. $92-108$

6. Тютюник В.В. Створення комплексної системи моніторингу надзвичайних ситуацій в регіонах України / В.В. Тютюник // Автореф. ... доктора технічних наук за спец. 21.02.03 - Цивільний захист. - Київ: НАН України. ДП «нститут геохімії навколишнього середовища НАН України». - 2015. - 42 с.

7. Тютюник В.В. Розвиток методологічного підходу для техногенно-екологічної оцінки рівня небезпеки функціонування структурних підрозділів потенційно небезпечних об’єктів та локальних територій України / В.В. Тютюник, В.М. Стрілець, В.Д. Калугін, Ю.В. Захарченко // Науково-технічний журнал «ТЕХНОГЕННО-ЕКОЛОГІЧНА БЕЗПЕКА», № 3(1/2018). - С.91 - 101 .

8. Розпорядження Кабінету Міністрів України від 25 січня 2017 року № 61-р. «Про схвалення Стратегії реформування системи Державної служби України 3 надзвичайних ситуацій» [Електронний ресурс]. - Режим доступу: http://zakon5.rada.gov.ua/laws/show/61-2017-\%D1\%80

9. Калугін В.Д. Розробка науково-технічних основ для створення системи моніторингу, попередження та ліквідації надзвичайних ситуацій природного та техногенного характеру та забезпечення екологічної безпеки / В.Д. Калугін, В.В. Тютюник, Л.Ф. Чорногор, Р.І. Шевченко // Системи обробки інформації. - Харків: Харківський університет Повітряних Сил імені Івана Кожедуба, 2013. - Вип. 9(116). - С. $204-216$.

10. Кодекс цивільного захисту України від 2 жовтня 2012 року № 5403-VI // Голос України. - 2012.- листопад (№ 220(5470)). - C. 4 - 20.

11. Постанова Кабінету Міністрів України від 9 січня 2014 року № 11 «Про затвердження Положення про Сдину державну систему цивільного захисту» [Електронний ресурс]. - Режим доступу: http://zakon5.rada.gov.ua/laws/show/112014-\%D0\%BF

12. Чорногор Л.Ф. Космос, Земля, людина: актуальні проблеми / Л.Ф. Чорногор. - 2-ге вид., доп. - Харків: Харківський національний університет імені В.Н. Каразіна, 2017. - 384 с.

13. Глушков В.М. Введение в теорию самосовершенствующихся систем / В.М. Глушков. - Киев: Изд-во КВИРТУ, 1962. -109 c.

14. Писклакова О.А. Анализ особенностей решения задачи многокритериальной оптимизации в условиях неопределенности / О.А. Писклакова, Н.А. Брынза, Д.И. Филипская // Системные технологии. Региональный межвузовский сборник научных работ - Вып. 3(56) - Днепропетровск, 2008. - № 01. - С. 147 - 157. 
15. Петров Э.Г. Анализ подходов к решению задачи поиска оптимального решения в условиях неопределенности / Э.Г. Петров, О.А. Писклакова // Вестник Херсонского национального технического университета. - 2007. - № 4(27). - C. $14-19$.

16. Петров Э.Г. Методы и модели принятия решений в условиях многокритериальности и неопределенности: монография / Э.Г. Петров, Н.А. Брынза, Л.В. Колесник, О.А. Писклакова; под ред. Э.Г. Петрова. - Херсон: Гринь Д.С., 2014. - $192 \mathrm{c}$.

Рецензент: д-р техн. наук, проф. М. І. Адаменко, Харківський національний університет імені В. Н. Каразіна, Харків Received (Надійшла) 26.06.2018 Accepted for publication (Прийнята до друку) 15.08.2018

\section{Основополагающие принципы создания в Единой государственной системе гражданской защиты информационно-аналитической подсистемы управления процессами предупреждения и локализации последствий чрезвычайных ситуаций}

\section{В. В. Тютюник, В. Д. Калугин, О. А. Писклакова}

Предметом изучения в статье являются процессы: сбора, обработки и анализа информации; моделирование развития обстановки на объекте управления и развития чрезвычайной ситуации (ЧС) на территории города, региона, страны; разработки и принятия управленческих решений в условиях многокритериальности и неопределенности при предупреждении и ликвидации ЧС, а также минимизации их последствий для решения прикладных задач Единой государственной системы гражданской защиты (ЕГСГЗ). Целью является развитие научно-технических основ создания информационно-аналитической подсистемы управления процессами предупреждения и локализации последствий ЧС Единой государственной системы гражданской защиты. Задача: техническая реализация в ЕГСГЗ информационно-аналитической подсистемы управления процессами предупреждения и локализации последствий ЧС путем комплексного включения в действующую ЕГСГЗ по вертикали от объектового до государственного уровней различных функциональных элементов территориальной системы мониторинга ЧС и составляющих системы ситуационных центров. Используемыми методами являются: методы системного, функционального и выпуклого анализа; методы разработки автоматизированных систем; методы принятия решений в условиях многокритериальности и неопределенности. Полученые результаты. Изложены основные принципы создания информационно-аналитической подсистемы управления процессами предупреждения и локализации последствий ЧС в ЕГСГЗ. Выводы. Научная новизна полученных результатов заключается в следующем: определено, что одной из основных функций системы ситуационных центров на всех уровнях управления ЕГСГЗ является разработка эффективных антикризисных решений, которая осложняется необходимостью учета их своевременности, полноты и оптимальности. Для повышения эффективности принятия решений обоснована необходимость разработки формальных, нормативных методов и моделей комплексного решения проблемы в условиях многокритериальности и неопределенности при управлении процессами предупреждения и локализации последствий ЧС.

Ключевые слова: чрезвычайная ситуация, Единая государственная система гражданской защиты, информационно-аналитическая система управления процессами предупреждения и локализации последствий чрезвычайных ситуаций, система мониторинга чрезвычайных ситуаций, система ситуационных центров, принятие решений в условиях многокритериальности и неопределенности.

\section{The making fundamental principles of the informational and analytical subsystem of prevention management processes and localization of emergency situation consequences within unified state civil protection system \\ V. Tiutiunyk, V. Kalugin, O. Pisklakova}

In this article processes of collecting, processing and analysis of information; modeling of situation development on object of management and development of the emergency situation in the territory of the city, the region, the country; developments and adoptions of administrative decisions in the multicriterial conditions and indeterminacy at prevention and elimination of emergency and also minimization of their consequences for the applied solution problems of the Unified State Civil Protection System (USCPS) have been studied. Development of scientific and technical bases of making fundamental principles of the informational and analytical subsystem of prevention management processes and localization of emergency situation consequences within USCPS was by the purpose. Technical realization in USCPS of an informational and analytical subsystem management of prevention processes and localization of emergency consequences by complex inclusion in operating USCPS vertically from object to state levels of various functional elements territorial system of monitoring emergency and system components of the situational centers was a task. The following methods have been used: systems, functional and convex analysis; developments of the automated systems; decision makings in the conditions of a multicriterial and indeterminacy. Obtained results. Making fundamentals of an informational and analytical management subsystem of prevention processes and localization of emergency consequences within USCPS have been explained. Conclusions. The scientific novelty of the received results consists in the following: has been defined that one of trial functions of situational system centers at all levels of USCPS management is development of efficient crisis response solutions which is complicated by need of accounting their timeliness and also completeness and optimality. Need of formal development, normative methods and models of a complex solution in the multicriterial conditions and indeterminacy at management processes of prevention and emergency situation localization consequences was proved for increase in effectiveness of a decision making.

Keywords: emergency situation, Unified State Civil Protection System, analytical subsystem of prevention management processes and localization of emergency situation consequences, the monitoring system of emergency situations, the system of the situational centers, a decision making in the conditions of a multicriterial and indeterminacy. 